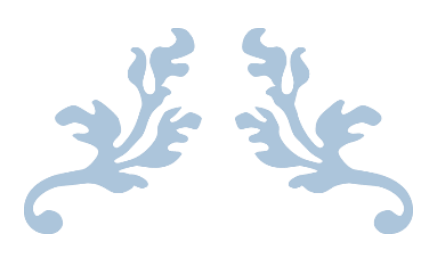

\title{
ACCOUNTABILITY IN CLIMATE CHANGE GOVERNANCE AND CARIBBEAN SIDS
}

Michelle Scobie PhD.

LIB (Hons), LEC, Dipl. Int. Rel. (Dist) Lecturer, International Law, Global Environmental Governance

Institute of International Relations \& Sir Arthur Lewis Institute for Social and Economic Studies The University of the West Indies St Augustine, Trinidad \& Tobago Skype: michellescobie scobiemichelle@gmail.com

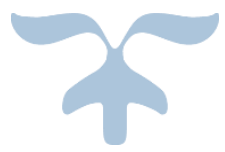




\section{Contents}

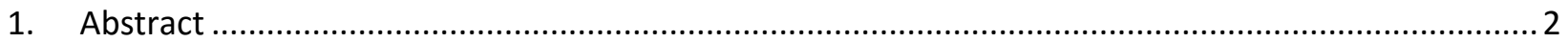

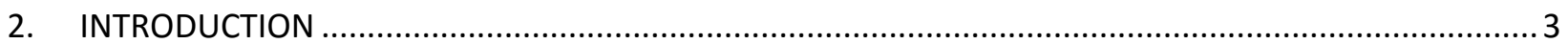

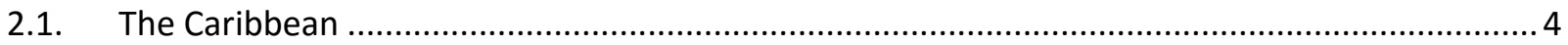

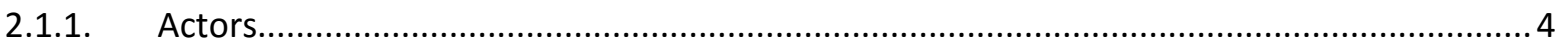

2.1.1.1. Figure 1. CARICOM MEMBER STATES ................................................................... 4

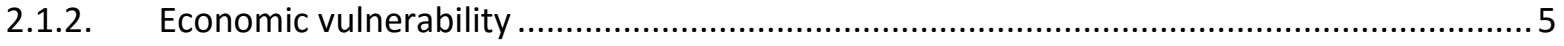

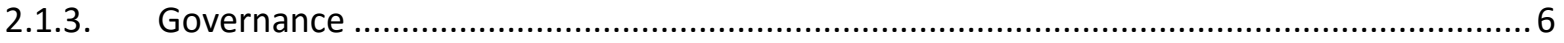

2.1.4. Figure 2-Government Effectiveness of Selected Caribbean States and the United States 8

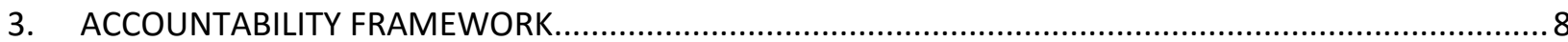

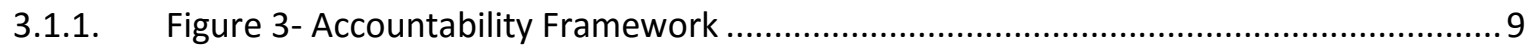

3.1.2. Figure 4-Levels of Accountability ........................................................................... 10

3.1.3. Figure 5- Accountability Relationships ................................................................ 11

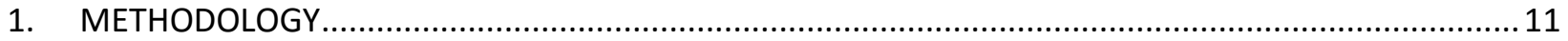

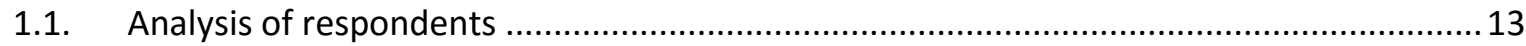

1.1.1. Figure- 6 - Survey Respondents - Geographic Scope ............................................... 14

1.1.2. Figure 7- Survey Respondents by sector ................................................................ 14

1.1.3. Figure 8- Respondents knowledge of Climate Change Governance by Caribbean Islands 14

1.1.4. Figure 9- Subject areas of expertise of survey respondents .......................................14

2. ACCOUNTABILITY IN CARIBBEAN CLIMATE CHANGE GOVERNANCE .......................................... 14

2.1.1. Figure 10- Percentage of actors using each governance mechanism ..........................15

2.2. LEVELS OF ACCOUNTABILITY (INTERNAL AND EXTERNAL) IN CARIBBEAN CLIMATE CHANGE

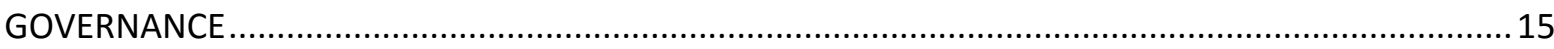

2.2.1. Figure 11- Caribbean Case: Levels of Accountability.................................................15

2.3. TYPES OF ACCOUNTABILITY RELATIONSHIPS (NORMATIVE, RELATIONAL, DECISION AND BEHAVIOUR) IN CARIBBEAN CLIMATE CHANGE GOVERNANCE ................................................

2.3.1.1. Figure 12. Percentage participation of actors in each type of accountability relationship 17

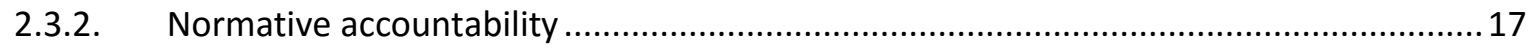

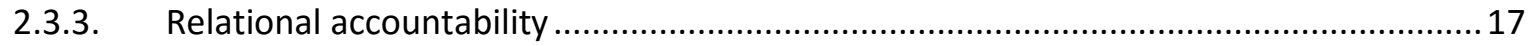




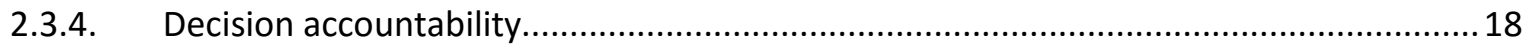

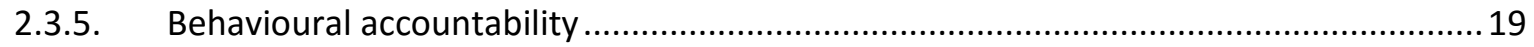

2.4. ACCOUNTABILITY MECHANISMS IN CARIBBEAN CLIMATE CHANGE GOVERNANCE...............19

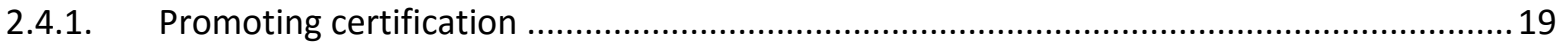

2.4.2. Promoting participation of stakeholders in overseeing sector projects ..........................20

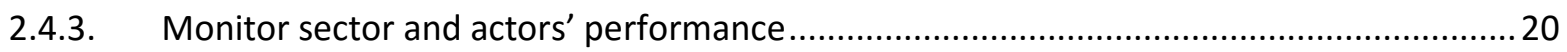

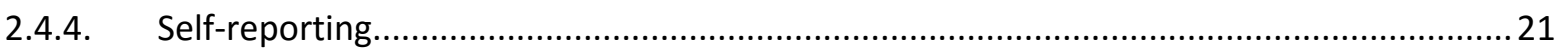

2.4.5. Figure 13- Percentage of actors that promote certification ......................................22

2.4.6. Figure 14- Percentage of actors that promote participation of stakeholders in

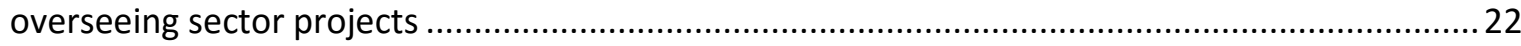

2.4.7. Figure 15- Percentage of actors that monitor sector and actors' performance .............22

2.4.8. Figure 16- Percentage of actors that regularly engage (at least annually) in selfreporting 22

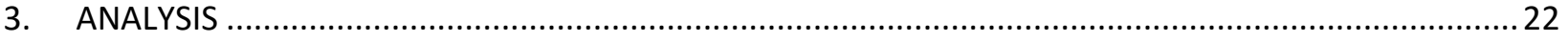

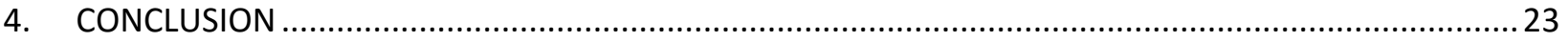

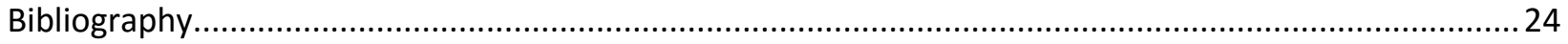

1. Abstract

Accountability is part of the good governance of institutions and regimes. The subject of this paper is nature of accountability in the climate change governance relationships. Context matters for understanding related governance dynamics and this paper presents the findings of research on accountability in climate governance in Caribbean SIDS over the last 18 years. It identified the Caribbean climate governance agents at the regional and local scales. It created an accountability framework that examined two levels (internal/external accountability); four accountability relationships (normative, relational, decision and behavioural) and four accountability mechanisms or processes: certification, monitoring, participation by stakeholders in the overseeing of projects and self-reporting. It analysed how far accountability was appreciated and applied within institutions and in relationships between regional institutions, international partners, government agencies, non-governmental organisations and the private sector to manage climate change adaptation and mitigation. The study found that accountability was valued as a good governance principle but the mechanisms to operationalise accountability were lacking in practice. The absence of structured processes was attributed to the economic and governance contexts of these SIDS. Governance actors had limited resources for governance safeguards. The study recommends processes to strengthen the "culture of governance" within the Caribbean as a whole and specifically within state agencies and civil society. 
Key words: SIDS, Governance, Accountability, Relationships, Governance Mechanisms,

\section{INTRODUCTION}

Context matters for understanding governance dynamics (Okereke 2010), (Underdal 2010)) and the question of how far accountability norms penetrate into climate change governance architectures in local contexts remains largely unanswered for the Caribbean.

This article answers the following questions: what frameworks can be used to assess the accountability relationships and mechanisms in climate change governance? How are those relationships and mechanisms operationalised in the Caribbean? Are actors accountable to their internal stakeholders, to their external stakeholders? What accountability mechanisms are most and least used in the region?

The governance and development challenges faced by Caribbean SIDS would suggest that accountability is weak in climate change governance and that this may explain the lack of consistency in climate governance efforts since 1997 when specific projects began. To date however there has been no attempt to theorise accountability nor has there been an empirical study to provide data on the link between weak governance and accountability in the Caribbean.

Accountability is part of good governance. The latter, used as a conditionality by multilateral financial institutions (MFIs), was criticised as neo-colonial rhetoric and not appreciated for that reason by many in the region (Girvan and Bernal, 1982). Yet the quality of governance matters for institutional effectiveness (Biermann et al. 2010 and Balsiger and Van Deveer 2012) and is helpful to gauge governance performance.

The study's focus is to theorise and report on the levels, mechanisms and relationships of accountability in the climate change governance. Although accountability is important for institutional effectiveness (Biermann et al. 2010; Biermann et al. 2012; (Schouten and Glasbergen 2011; Keohane and Victor 2011) and perceptions of effectiveness by stakeholders (Dellas 2011), this study does not analyse accountability in terms of effective outcomes. Effectiveness in environmental governance has been theorised in the literature by Mitchell and others. This study opens future research agendas that can apply these accountability frameworks to outcomes to determine how the elements of the framework contribute in different contexts to effective outcomes.

The article developed a framework of accountability levels (internal/external) (Keohane 2003); accountability relationships (normative, relational, decision and behavioural) (Biermann and Gupta 2011) and accountability mechanisms (certification, stakeholder participation, performance monitoring and self-reporting) to analyse accountability in the region. 


\subsection{The Caribbean}

Context is important to understand the accountability deficits found in the study. The multiplicity of actors and a variety of challenges help explain the difficulty in applying many of the accountability mechanisms mentioned above.

\subsubsection{Actors}

The Caribbean has many agencies that manage regional climate governance. Most national climate change departments and agencies are small with between 2-15 persons and must engage in multiple regional and national forums.

The Caribbean Community (CARICOM) is the highest regional decision making body, it broadly shapes regional agendas through the Heads of Government meetings.

\begin{tabular}{|l|l|}
\hline \multicolumn{2}{|l|}{ CARICOM MEMBER STATES } \\
\hline Antigua and Barbuda & Jamaica \\
\hline The Bahamas & Montserrat \\
\hline Barbados & Saint Lucia \\
\hline Belize & St. Kitts and Nevis \\
\hline Dominica & St. Vincent and the Grenadines \\
\hline Grenada & Suriname \\
\hline Guyana & Trinidad and Tobago \\
\hline Haiti & \\
\hline
\end{tabular}

2.1.1.1. Figure 1. CARICOM MEMBER STATES

Climate Change governance began in earnest in 1997 when CARICOM coordinated three main projects for adaptation planning and mainstreaming of climate change in developmental projects between 1997 and 2007 (CARICOM 2014). Several pilot projects were carried out until the eventual creation of the Caribbean Community Climate Change Centre (CCCCC) which has CARICOM's mandate to coordinate regional adaptation and mitigation efforts. The work of the CCCCC is often at the margin of national and community adaptation strategies in individual states unless funding or assistance came through the CCCCC.

Many other institutions form part of regional climate governance architecture and small national departments are challenged to engage them all: the Organisation of Eastern Caribbean States (a sub-regional political grouping) ${ }^{1}$, the Association of Caribbean states (all states around the

${ }^{1}$ The Organisation of Eastern Caribbean States is a political organisation and economic union and an important subset of Caribbean States comprising Antigua and Barbuda, Commonwealth of Dominica, 
Caribbean Sea including parts of Central and South America); the Organisation of Eastern Caribbean States (OECS) and a network of issue-specific state and non-state agencies whose mandate connects with climate change in areas such as coastal health, financial planning, and health and water management ${ }^{2}$. Regional non-profit organisations in the larger Caribbean islands have relationships with the state agencies and community groups and promote education, vulnerability assessment, capacity building for policy making and building ecosystem based solutions especially in areas such as fishing, tourism, water supply and management, wildlife and specie conservation and forest management.

\subsubsection{Economic vulnerability}

SIDS are vulnerable to external shocks, their small and open economies crumble with changes in global demand or a fall in local production caused by natural disasters (Sanders 1997).

Caribbean SIDS face a heavy debt burden and limited fiscal space (Alleyne et al. 2014). Public debt in the region was in excess of 76 per cent of GDP, and reached 103 percent of government revenue in Jamaica in 2009.

The economic costs of climate change were (conservatively) estimated at between $1.5 \%$ and 5 percent of GDP for Latin America and the Caribbean with even higher social and environmental costs (Samaniego et al. 2014, pg 8). Adaptation costs were conservatively estimated to increase to US10.7 billion dollars by 2025 to address infrastructure and tourism losses caused by hurricanes (Vergara et al. 2013).

What economist call indivisibility of costs exacerbates resource limitations: the cost for example of shoreline protection infrastructure per-capita is higher than the unit cost for similar installations in a larger country with larger territory, population and tax revenue base. An extreme event like a hurricane has a disproportionate impact on GDP as compared to a larger country where such an extreme event will impact upon a smaller proportion of its territory and population (Barros, et al. 2014).

Grenada, Montserrat, St Kitts and Nevis, St Lucia and St Vincent and the Grenadines with associate members Anguilla and the British Virgin Islands. These smaller Caribbean Islands have a strong degree of functional cooperation on legal, financial, economic, social and environmental affairs through the OECS Authority, Council of Ministers, the OECS Assembly, Economic Affairs Council, the OECS Commission, the Eastern Caribbean Supreme Court, Civil Aviation Authority and Central Bank.

${ }^{2}$ They include the Caribbean Public Health Agency; the Caribbean Agricultural Research \& Development Institute; the Caribbean Development Bank, and the Caribbean Water and Waste Water Association; the Caribbean Meteorological Organisation; the Caribbean Tourism Organisation; the Food and Agricultural Organisation of the UN, Inter-American Development Bank; Inter-American Institute for Cooperation on Agriculture; International Labour Organisation; UN Economic Commission for Latin America and the Caribbean; United Nations Development Programme; the United Nations Information Centre; the Caribbean Natural Resources Institute; Intasave-Caribsave Group; Council of Presidents of the Environment; Papa Bois Conservation and Environment Tobago. 
Caribbean tourism amounts to $38 \%$ of total exports for the region and that figure rises in some states to as much as 70\%. Sea level may rise by 0.5-0.6 meters and 49-60 percent of tourist resort properties may be damaged (Barros, et al. 2014; Scott, Simpson, and Sim 2012). The tourism industry may face up to a US\$146 million loss of revenue because of climate change (Moore 2010). Projections estimate massive coral bleachings in 2074 and already in some places (Bermuda's Hungry Bay for example) mangroves are being depleted by rising sea levels.

\subsubsection{Governance}

According to the IPCC Fifth Assessment Report, climate change has three main areas of impact for SIDS: coastal systems, terrestrial systems and human systems. There is a high to very high degree of confidence that environmental and human systems are being impacted upon by climate change. The Report has a very high degree of confidence that sea levels will rise; that there will be general environmental degradation and loss of habitat in urban locations; that there will be more casualties and damage during extreme events; that there will be more coral bleaching; an incremental degradation of ground water quality; increased shoreline erosion and degraded coastal fisheries. There is a medium to high degree of confidence that there will be altitudinal species shift, saline incursions degrading ecosystems, acidification of surface waters, and increased human susceptibility to climate induced diseases. The 2014 IPCC report documents already existing impacts on coasts and marine biophysical systems, on terrestrial systems and water resources, on human settlements, tourism, health and economies.

Adaptation is an important part of policy response in climate change governance for SIDS as climate change is projected to cause more intense extreme events and less favourable conditions for main sectors such as tourism and agriculture. Temperatures may rise by as much as $1.4{ }^{\circ} \mathrm{C}$. Rainfall is projected to decrease by 5 or 6 per cent in much of the Caribbean by 2100 - which will negatively affect agriculture and water availability. Public health impacts are a significant cause for concern as some vector (zika and dengue), food and water borne diseases can be exacerbated by climate change. In recent times, climate change led to extreme drought in Jamaica, to flooding in Guyana in 2005 and Belize in 2010 and the recent increase incidence of dengue in Trinidad and Tobago was attributed to increased rainfall caused by climate change (Barros, et al. 2014; Nurse, et al. 2014). Much of Guyana's built areas are below the sea level and rising sea levels threaten its sea walls that separate its capital from the Atlantic Ocean. This existential risk is not matched by the resources to rebuild sea walls nor to move entire populations inland.

Adaptation, defined as the process of adjustment to actual or expected climate and its effects, is, according to the IPCC the only effective way to manage climate change when mitigation measures cannot reduce impacts. Adaptation policy has 10 broad areas of focus: development, poverty alleviation, livelihood security, disaster risk management, ecosystem management, spatial or land use planning, structural/physical actions (including engineered, technological, ecosystem based options and services), institutional actions, social actions (changing behaviour, informational and educational options), and other broad spheres for change (practical, political and personal adaptation strategies) (Nurse, et al. 2014 and Barros, et al. 2014). 
Adaptation for SIDS means policies for improved irrigation, water infrastructure, protection of coastal areas and infrastructure from storm surges and sea level rise, the development of early warning systems, climate resilient housing, health infrastructure, the development of marine parks and marine protected areas and mangrove and coral restoration to reduce the negative impacts of climate change and desalination plants for water security especially in heavily tourist dependant states etc. (Agrawala et al. 2010). In agriculture sector adaptation policy means finding ways to weather intense climate events, to develop pest resistant crops and strengthen resilience. For most Caribbean States that are not oil producers, adaptation also means finding low energy alternatives to expensive fossil fuels that cost the region up to US37 million in foreign exchange and reduces the competitiveness of Caribbean exports (CCCCC 2014).

Government departments and NGOs lack financial and technical resources, human capacity, data for comprehensive climate change and socio-economic scenarios (Nurse, et al. 2014) and heavily depend on intermittent donor project financing for adaptation and mitigation programs. The countries lack of absorptive capacity when they get donor funding (Brown et al. 2013). National agencies, even in larger states ${ }^{3}$, often lack the institutional prerequisites to access climate funds (management and reporting structures) (Bugler and Rivard, 2012). There is also the governance risk of what the IPCC calls maladaptation: with inadequate coordination among decision makers and lack of timely relevant data for policy and decision making, localised climate change adaptation interventions may increase the vulnerability of another area or sector to climate change.

Governance effectiveness - or what some persons in the region call a "culture of governance" is low for many Caribbean states. Table $\mathbf{5}$ shows the generally poor performance of the region for the World Bank's Government Effectiveness Indicator. The indicator which ranges from -2.5 to 2 is inter alia designed to capture perceptions of the quality of public services and of the civil service, the quality of policy formulation and implementation, and the credibility of the government's commitment to such policies. Weak governance limits the timely and effective implementation of climate adaptation and mitigation policies.

\footnotetext{
${ }^{3}$ The accredited National implementing agency in Jamaica for example, lacked capacity to manage funds and to keep to the fiduciary standards from the Adaptation Fund accessed under the UNFCCC (Bugler and Rivard, 2012). The Case of Grenada mirrors the Jamaican experience. In September Hurricane Ivan and soon after Hurricane Emily devastated Grenada and the country obtained funding for a Pilot Program for Climate Change Resilience. Project funds were time bound however and on completion the country did not have the capacity and is challenged to maintain integrated climate change strategies (Darylmple and Mason-Case 2012).
} 


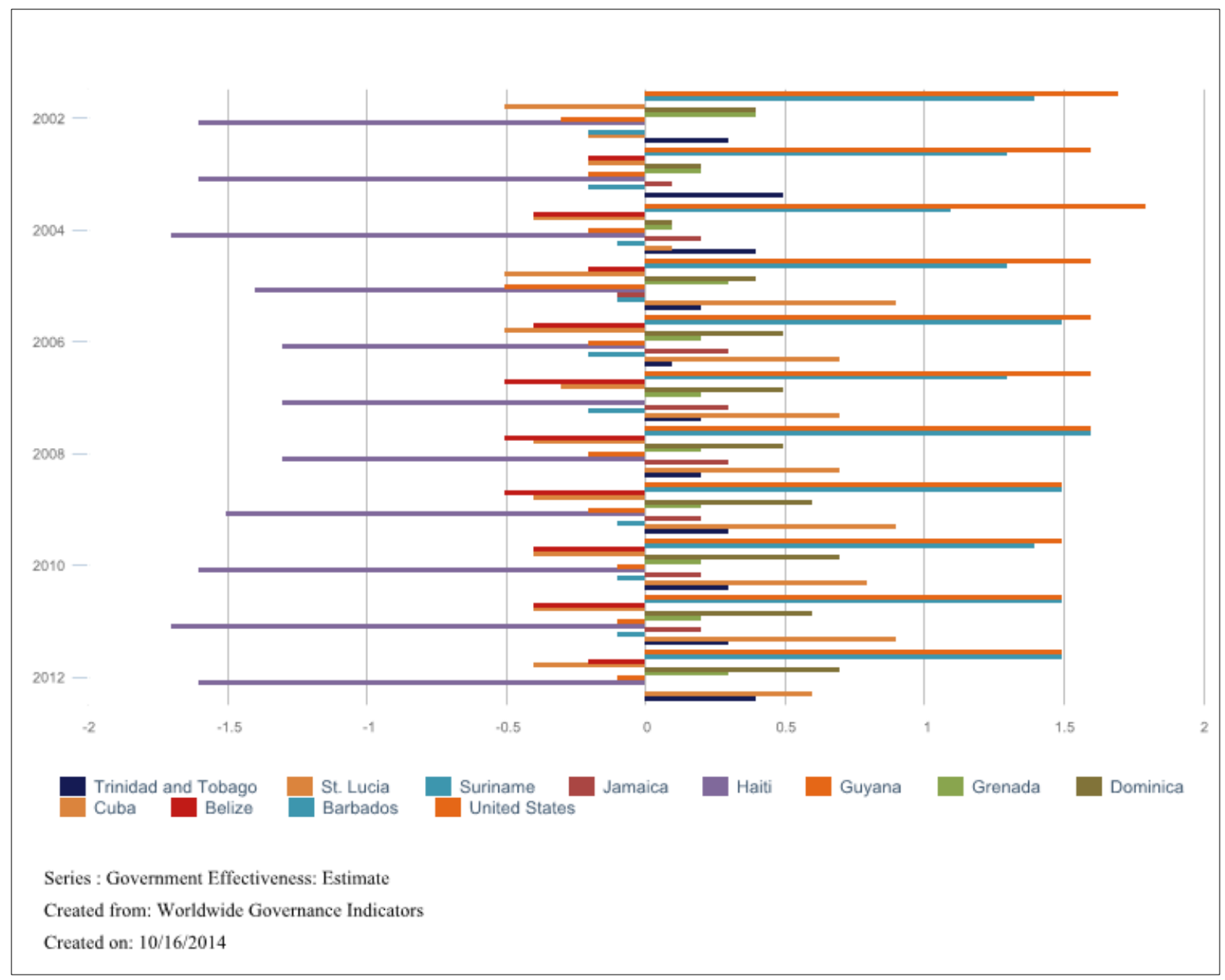

2.1.4. Figure 2-Government Effectiveness of Selected Caribbean States and the United States

In the sections that follow, after explaining the conceptual framework of accountability levels (internal and external), types (normative, relational, decision and behavioural) and mechanisms (certification, monitoring, participation by stakeholders and self-reporting within the framework accountability relationship types), the paper outlines the methodology, and presents the findings of the research on the availability and use of accountability mechanisms.

\section{ACCOUNTABILITY FRAMEWORK}

Governance processes have changed over the years and are managed not only through traditional political state regulation or control, but also through pressures of norms and values, through partnerships with science and technology to solve common problems and through the market (Andonova and Mitchell 2010); (Biermann, Pattberg, and Zelli 2010); March and Olsen 1989). There is no consensus on what are the best practical processes and functions related to environmental governance. Environmental governance includes handling risks and stresses, 
transforming economic development, ensuring a diversity of options across natural, social and economic systems (Nilsson and Persson 2012); agenda setting, implementation of mandates, cooperation and creating cooperative relationships, regulation and enforcement, monitoring, capacity building and information sharing (Keohane and Nye 2000). These processes necessarily create accountability relationships between actors.

Climate governance is a systems governance problem that requires better cooperation between actors and institutions across geographical scales (Walker et al. 2009). We still need to better understand what architectures and interactions can best support environmental sustainability and climate change adaptation policy and programs (Dovers and Hezri 2010; Lahsen et al. 2010).

Four of the processes of governance most related to promoting the accountability were chosen for this study to fill a contextual gap in the accountability literature. Not enough of climate governance focuses on middle and low income countries (Lankao 2007) and more study is needed on the relevance of the contexts (Okereke 2010; Burton et al. 2002) as these influence the nature of decision making (Cash and Moser 2000),91) especially in vulnerable countries (Barnett 2010; Adger 2006).

\section{Accountability Framework}

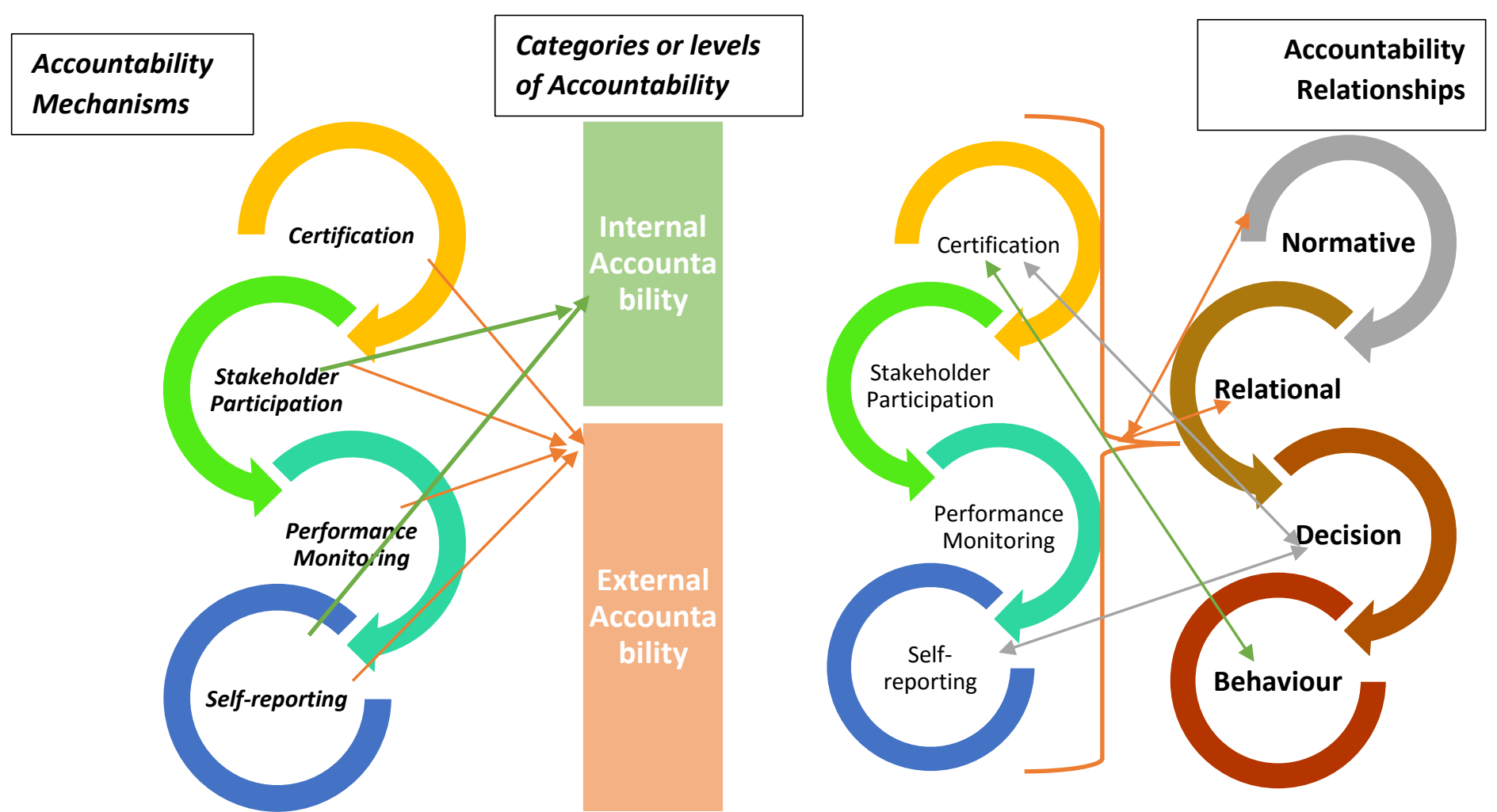

3.1.1. Figure 3- Accountability Framework 
Levels: there are two levels or what Keohane refers to as categories (internal and external) of accountability (Keohane 2003). Internal accountability helps explain the nature of formal principal-agent relationships within institutions and is exercised through mechanisms such as oversight by internal stakeholders and self-reporting of persons and departments within the organisation. External accountability refers to the indirect linkages between those acting and those (outside the formal structure) whose lives are impacted upon. External accountability can be exercised through certification (of processes by external third parties), stakeholder participation; by promoting the monitoring of the sector's and actors' performance and by selfreporting.

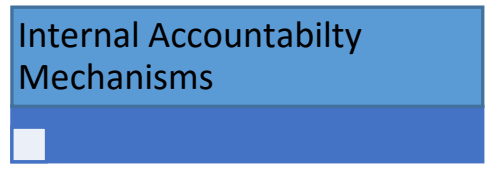

Internal Stakeholder Participation $\square$ Self-reporting

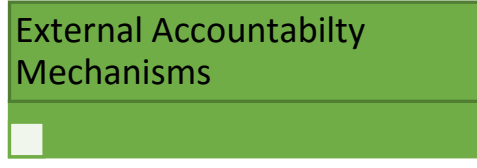

Certification

Stakeholder Participation

Performance Monitoring

Self-reporting

\subsubsection{Figure 4-Levels of Accountability}

Relationships: there are four types of accountability relationships (Grant and Keohane 2005; Biermann and Gupta 2011; Keohane and Victor 2011). Normative accountability is accountability due because there are standards or norms of behaviour that actors are expected to comply with (may lead to processes of self-reporting and compliance monitoring for example).

Relational accountability refers to relationships created between those should be accountable and those who have a right to that accountability (creates relationships of reporting and monitoring for example). Decision accountability refers to the judgement made by the latter (or third parties) on the behaviour of those who should be accountable (certification programs for example analyse and decide on the quality of the behaviour of actors for example). Behavioural accountability gives power to those who hold actors accountable to impose penalties or sanctions for failure to keep to pre-established standards of behaviour (for example through formal legal processes or naming and shaming of actors by NGO watchdogs). 


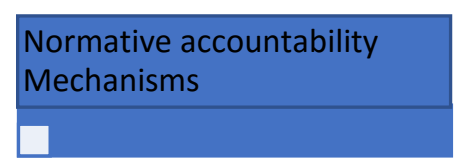

Certification

Stakeholder Participation

Performance Monitoring

Self-reporting

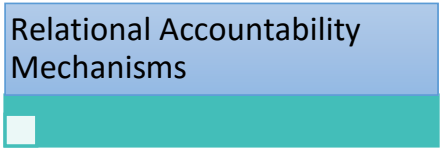

Certification

Stakeholder Participation

Performance Monitoring

Self-reporting

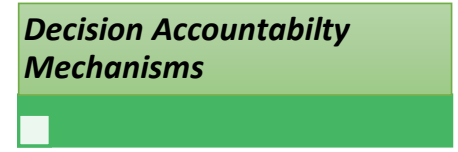

Certification

Self-reporting
Behaviour Accountabilty

Mechanisms

Certification

\subsubsection{Figure 5-Accountability Relationships}

The most common accountability mechanisms in the literature and which were chosen for this study were: certification, stakeholder participation, performance monitoring and self-reporting.

Climate governance actors use different mechanisms to provide and demand accountability in these relationships at internal and external levels of organisations and departments.

All four mechanisms are useful in external accountability while stakeholder participation (within departments) and self-reporting are most common in the case of internal accountability (within an organisation). All four mechanisms are useful in normative and relational accountability relationships. Certification and self-reporting are suited to decision accountability relationships and behaviour accountability can exercise sanctions through certification mecahnisms.

\section{METHODOLOGY}

The study was undertaken during period December 2013 to June 2015.

The first stage of the study mapped the actors that formed part of the regional climate change governance architecture. It identified actors that have been involved in establishing or implementing climate governance initiatives that had a regional focus/mandate or authority: interstate agencies, national agencies, the private sector, NGOs (including community based organisations) between 1997 and 2014. Data was obtained from a desk study of websites, reports, project documents and from surveys completed by the main actors. This data was enhanced with follow-up semi-structured interviews. The information was collected and collated through a Microsoft Excel program according to scale/level of actor action (regional to local); type of actor (state/private sector/non-state); functions and type of activities carried out (climate specific of tangentially climate related); geographic area of action (regional projects/local projects). 
Many of the initiatives that related to climate impacts were not directly considered climate change projects or activities, care was taken to include all those actors that mentioned that climate change affected their mandate and that were involved in the governance or management of projects that had climate change adaptation or mitigation impacts. The region does not yet have comprehensive reporting on regional and local climate change activities and initiatives, and there may be activities and actors not captured at all or only in part by the sources used in this study. The data collected represents the major actors and representative NGOs and private sector groups and their governance activities. It is the first attempt to map accountability from a climate change perspective for Caribbean SIDS.

The second stage mapped the extent to which four accountability mechanisms were available and used at regional to local scales. It was done through an online survey administered to these actors. Respondents reported on whether each of the mechanisms were either a) in their mandate and often part of their activities; $b$ ) in their mandate but seldom part of their activities; c) not in their mandate but often part of their activities or d) not in their mandate and seldom part of their activities. Responses gave a good indication of the value given to each mechanism (cases where there was a specific mandate to include the mechanism) as well as the regularity of use of each mechanism.

Participants were in all cases directors of these institutions or agencies or senior division heads. Most of the respondents worked at international, regional and national scales. Respondents had substantial knowledge of climate change governance in all of the Caribbean SIDS. Seventeen of them worked specifically in climate change and development projects but all of them included climate change governance as part of other development initiatives from tourism to agriculture to biodiversity.

Each agency directly worked with or engaged between 50 and 6000 persons on an annual basis. Many respondents counted the entire population of their country (or for the regional agencies the entire regional population) as the direct beneficiaries of their programs- the figures ranged from 220 million for the regional agencies responses to "several hundred" or "thousands" for the NGOs. Reported operational annual budgets ranged from an average of 115,000 US for some private sector agencies to 3 million for the national agencies.

The survey asked actors to state whether these accountability mechanisms were in their mandate and or a regular part of their activities: promoting certification; the participation of stakeholders in overseeing sector projects; monitoring the sector and the performance of actors in the sector and (at least) annual self-reporting.

The third stage of the study consisted of semi structured interviews that were between 30 minutes to $1 \frac{1}{2}$ hours with survey participants that indicated a willingness to participate in a follow-on interview. The interviews gave respondents an opportunity to explain survey responses. The interviews focused specifically on accountability and gave respondents an opportunity to share information on two specific points- first, how their organisation manages internal and external accountability in governance (using the survey questions as the basis of the discussion) and second how accountability is managed within the sector (by other actors at regional and local scales). 
The Caribbean region is small and the subject matter experts on climate change meet and share efforts at multiple regional and national forums leading to a good shared understanding of the governance realities of each agency. 20 of the 22 respondents to the survey were interviewed. Though the sample size was relatively small, the level of seniority within their organisations and the mix of public, private, NGO and technical agency subject-matter experts provided an objective and authoritative picture of the reality of accountability across the region. Generally their perspectives were not contradictory.

\subsection{Analysis of respondents}
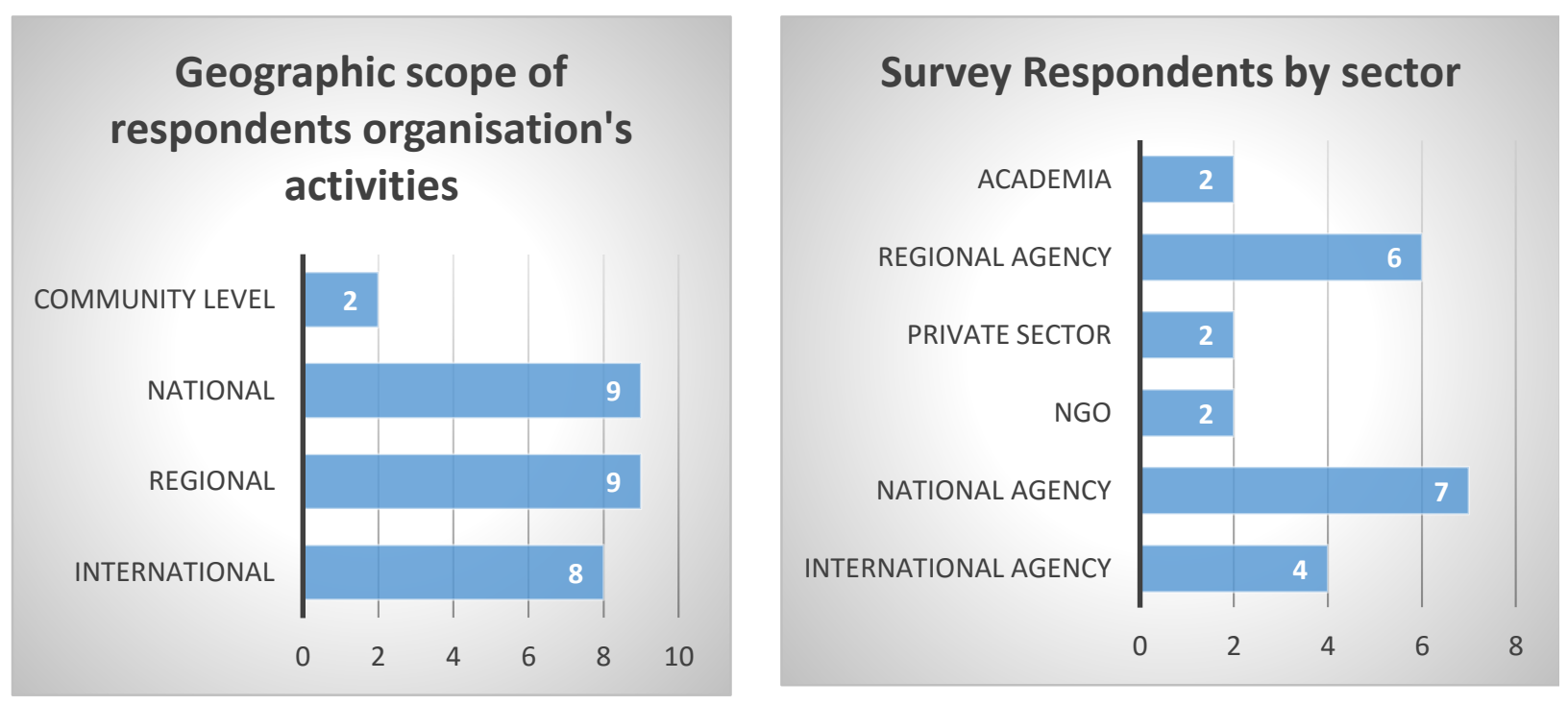


\subsubsection{Figure- 6 - Survey Respondents - Geographic Scope}

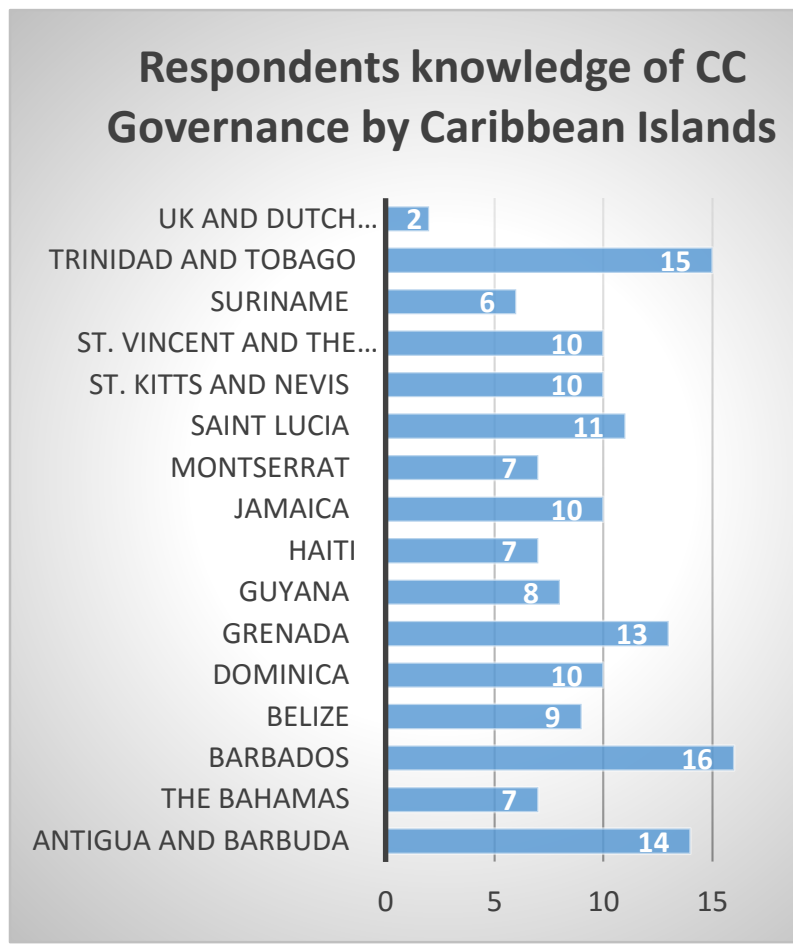

1.1.3. Figure 8-Respondents knowledge of Climate Change Governance by Caribbean Islands

\subsubsection{Figure 7- Survey Respondents by sector}

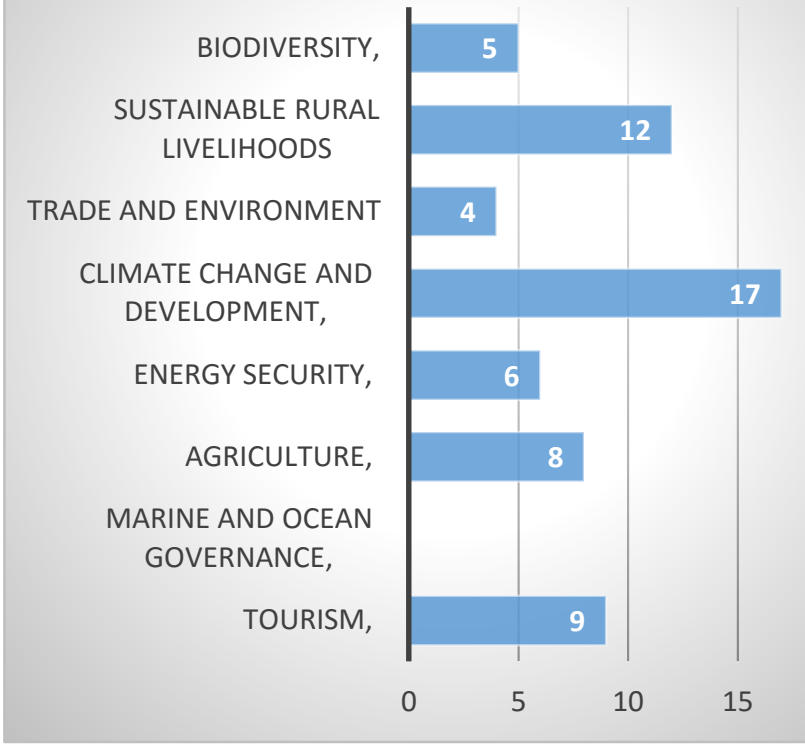

1.1.4. Figure 9- Subject areas of expertise of survey respondents

\section{ACCOUNTABILITY IN CARIBBEAN CLIMATE CHANGE GOVERNANCE}

Using the accountability framework discussed above, the survey and interviews provided data on the levels at which accountability is exercised (internal and external); on the types of accountability relationships (normative, relational, decision and behaviour) and on the accountability mechanisms most used (certification, involvement of stakeholders in overseeing and monitoring of projects, monitoring performance of actors within the sector and selfreporting). 


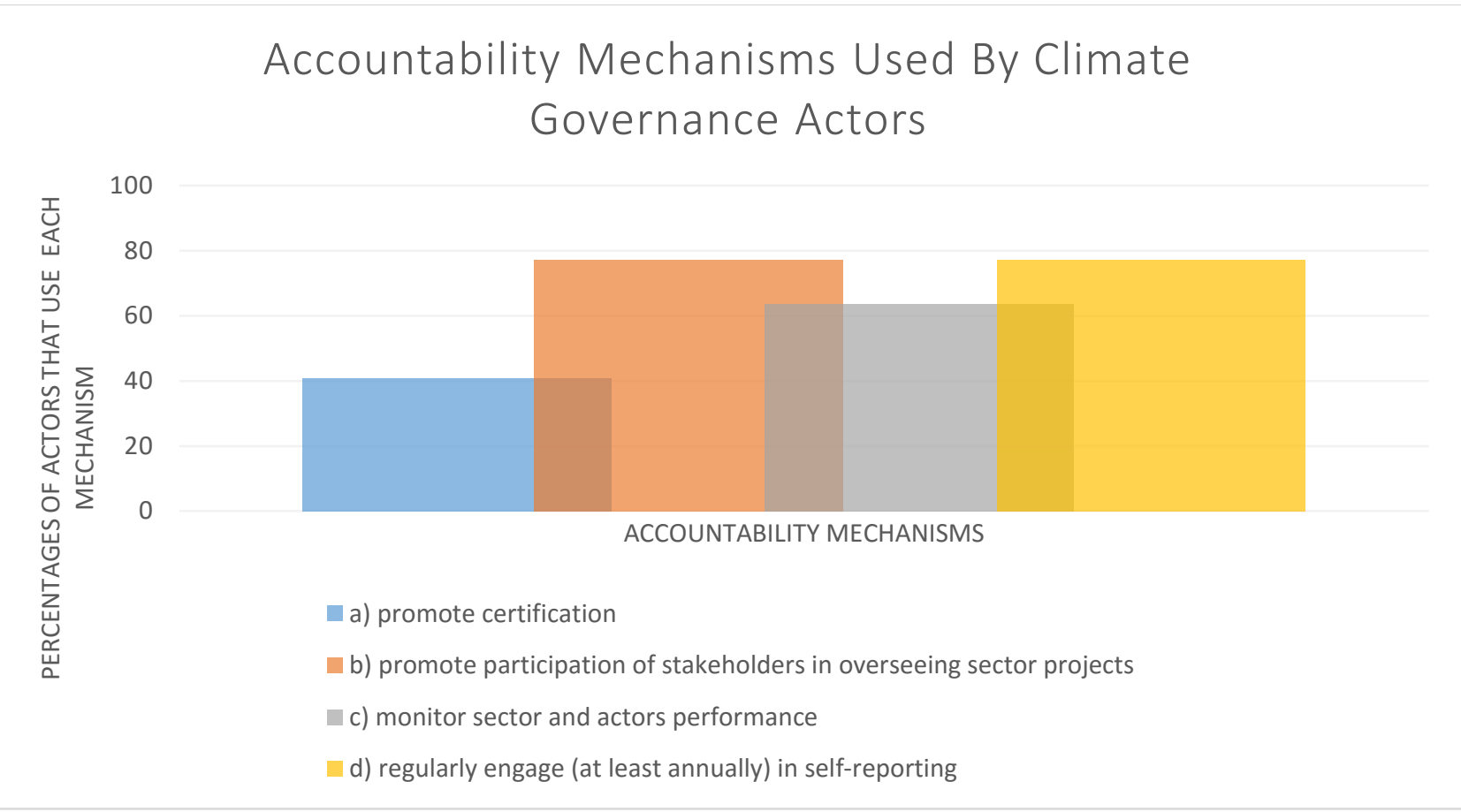

2.1.1. Figure 10- Percentage of actors using each governance mechanism

2.2. LEVELS OF ACCOUNTABILITY (INTERNAL AND EXTERNAL) IN CARIBBEAN CLIMATE CHANGE GOVERNANCE

\begin{tabular}{|l|l|}
\hline $\begin{array}{l}\text { Internal Accountabilty } \\
\text { Mechanisms }\end{array}$ & $\begin{array}{l}\text { External Accountabilty } \\
\text { Mechanisms }\end{array}$ \\
$\square$ Stakeholder Participation & $\begin{array}{l}\text { Certification } \\
\square \text { Self-reporting }\end{array}$ \\
& Stakeholder Participation \\
& $\square$ Performance Monitoring \\
& $\square$ Self-reporting \\
\hline
\end{tabular}

2.2.1. Figure 11- Caribbean Case: Levels of Accountability

Internal accountability can be measured by the existence of mechanisms for stakeholder participation and self-reporting within the organisation. External accountability can be 
measured by all four mechanisms: a) certification, b) stakeholder participation, c) performance monitoring and d) self-reporting.

Regional organisations, national agencies, the private sector and NGOS in the region were on aggregate marginally stronger on internal (average of seventy-seven percent) than on external accountability (average of sixty-five percent). However, the interviews revealed that when agencies applied accountability mechanisms they did so selectively.

International and regional organisations were stronger on internal accountability. They engaged in self-reporting via annual or periodic reports as part of the duty to report to member states on progress in implementing decisions and in the use of member contributions. State agencies did not systematically budget time and resources into their work streams for any form of internal accountability. There were cases of reporting by public officials to their principals or line ministers on policy planning and Implementation but this was ad hoc and few cases of regular reporting were driven by the personal initiative of a department head. Government officials explained that in many cases there was a culture of hoarding of information within state departments rather than a thrust for internal stakeholder participation. It was not uncommon that colleagues from the same or closely related departments would not share information or brief them on their activities or meetings with international, regional or local agencies. Much less was there a duty to involve other internal stakeholders through accountability processes.

The study found that NGOs had most difficulty with internal accountability. Most of the climate related NGOs were small, with limited budgets and did not have developed internal mechanisms. Their boards of directors often lacked the capacity, organisation or time to provide needed oversight. NGOs tended to engage in self-reporting when engaged in projects requiring foreign funders. Attempts are being made in the Caribbean to help NGOs build capacity through Civil Society Accountability toolkits for example

External: external accountability was marginally less (twelve percentage points) than internal accountability, respondents considered that climate governance actors were not sufficiently accountable to stakeholders external to their organisations and explained that that this governance problem was not limited to climate change.

According to the survey, forty percent of the organisations promoted certification and about sixty percent were engaged in monitoring. Respondents explained that in reality, though they promoted certification programs among members, few were certified and monitoring and stakeholder engagement were irregular and not systematic and will be explained in further detail below.

\subsection{TYPES OF ACCOUNTABILITY RELATIONSHIPS (NORMATIVE, RELATIONAL, DECISION AND BEHAVIOUR) IN CARIBBEAN CLIMATE CHANGE GOVERNANCE}




\begin{tabular}{|c|c|c|c|}
\hline $\begin{array}{l}\text { Normative accountability } \\
\text { Mechanisms }\end{array}$ & $\begin{array}{l}\text { Relational Accountability } \\
\text { Mechanisms }\end{array}$ & $\begin{array}{l}\text { Decision Accountabilty } \\
\text { Mechanisms }\end{array}$ & $\begin{array}{l}\text { Behaviour Accountabilty } \\
\text { Mechanisms }\end{array}$ \\
\hline & & & \\
\hline Certification $-41 \%$ & Certification-41\% & $\square$ Certification-41\% & Certification-41\% \\
\hline $\begin{array}{l}\square \text { Stakeholder Participation- } \\
77 \%\end{array}$ & $\begin{array}{l}\text { Stakeholder Participation- } \\
77 \%\end{array}$ & $\square$ Self-reporting-77\% & \\
\hline$\square$ Self-reporting-77\% & Self-reporting-77\% & & \\
\hline
\end{tabular}

\subsubsection{Figure 12. Percentage participation of actors in each type of accountability relationship}

\subsubsection{Normative accountability}

Normative accountability in this study was understood as a duty to keep to a recognised standard of behaviour. It requires clear standards and a duty to others to conform behaviour to those standards (through certification, stakeholder participation, performance monitoring and selfreporting).

This form of accountability represented sixty-five percent of accountability efforts according to survey responses. Many respondents equated engaging stakeholders through ad-hoc stakeholder forums with accountability and stated that both public and private sectors had not yet developed a true "culture of accountability" or a "culture of governance".

Normative accountability was stronger where agencies outside of the region (donor or headquarter offices of international organisations or transnational companies) required preestablished standards of behaviour of its loan or grant recipients or sub-offices. Most national agencies did not have behavioural standards or reporting matrices for internal or external accountability. NGOs were critical of the low quality of normative accountability of state agencies that consisted mainly of irregular internal self-reporting and sporadic stakeholder forums.

\subsubsection{Relational accountability}

Relational accountability in this study was understood as relationship created when some actors had a right to hold others to recognised standards of behaviour (through certification, stakeholder participation, performance monitoring and self-reporting). Most actors surveyed responded positively to exercising this type of relationship. It accounted for sixty-five percent of accountability efforts. The feedback from the interviews however was that this accountability 
was practiced selectively and narrowly construed. It was strongest when projects involved external/foreign funding agencies. Those projects were awarded with conditionalities such as the holding of regular meetings with local stakeholders and incorporating feedback into project development. Outside of those engagements, many respondents stated that there was little evidence of such relationships either within agencies or between agencies and outside stakeholders.

Most international agencies attributed their accountability practices to established standards of their headquarter organisations. Most regional organisations did not have similar mechanisms by which member states and external stakeholders could hold them to account. The ACS for example focused on promoting political cooperation between regional governments and partnering with national agencies to support national activities and would follow the latter's lead on accountability mechanisms and processes.

NGOS reported that national climate change governance was "top down", "lacking transparency" with "superficial consultations". Officials from regional and national agencies believed that they should be strictly accountable only to their political bosses. They did not see themselves as having a duty to report to or having accounting relationships with other departments and external stakeholders such as the general public, the private sector or NGOs. Information sharing via public consultations or posting information on websites was seen as part of outreach and not accountability.

A noteworthy exception to this general trend was Organisation of Eastern Caribbean States (OECS) Commission that serviced the political grouping of the smaller Eastern Caribbean islands that had institutionalised mechanisms to promote accountability and participation and to foster certification as part of its mandate.

Another positive case of relational accountability was way the government of Grenada engaged civil society during the Sustainable Development National Planning Processes. Respondents however cautioned that without external funding, neither party would have the resources to sustain that relationship into monitoring, evaluating and implementation stages.

\subsubsection{Decision accountability}

Decision accountability in this study was understood as the processes (e.g. certification and selfreporting) that gave actors the opportunity to judge whether others were keeping to established standards of behaviour. The study found that it was, after behavioural accountability, second weakest area of accountability in the Caribbean- accounting for thirty percent of accountability efforts.

Established standards of behaviour reporting were not readily available for most agencies and the processes to assess or judge behaviour were also not available in most cases. Seventy-seven percent of the respondents engaged in some form of internal self-reporting. However, the reporting process did not give external stakeholders an avenue to assess behaviour. Respondents recognised that certification could be a good step towards decision accountability but found existing international programs were not well suited to local realities. Local actors- other than 
large private regional and international corporations did not have the expertise and resources to obtain and maintain certification. Developing Caribbean-appropriate certification in climate change for both public and private actors may facilitate decision accountability.

\subsubsection{Behavioural accountability}

Behavioural accountability in this study was understood as a right to impose penalties or sanctions when established or recognised standards of behaviour were not met (e.g. through certification). There was little evidence of this type of accountability relationship in climate governance in the region.

In the case of external donors, there was some behavioural accountability as donors were able limit future funding if there were serious omissions in keeping to project standards. Regional agencies noted however that for government led projects, donors were generally reluctant to sanction and to prescribe monitoring and evaluation by stakeholders outside of the government for it would be intervening in national policy. At the national level government agents were not sanctioned for non-reporting, not monitoring the performance of actors in the sector nor for failures to engage stakeholders in accountability processes since resources were usually not assigned for these processes. At the level of NGOs, their strongest internal sanction should come from their own board of directors. In the region these organisations are small, their Boards often work on a voluntary or almost voluntary basis and often lack time and capacity to critically examine or sanction behaviour.

Having examined internal and external accountability and the different types of accountability relationships, the next stage of the paper examined the ways in which the four mechanisms outlined above (a) certification, b) stakeholder participation, c) performance monitoring and d) self-reporting) were used by climate governance actors in the region.

\subsection{ACCOUNTABILITY MECHANISMS IN CARIBBEAN CLIMATE CHANGE GOVERNANCE}

This part of the paper reported on how extensive was the use of each of the accountability mechanisms according to actor types.

\subsubsection{Promoting certification}

Forty-one percent of the agencies promoted certification. International organisations were responsible for about thirty-four percent of the effort, national agencies and the private sector each accounted for about twenty-two percent of the efforts to promote certification in the region. In the interviews respondents clarified that in many cases, those efforts were to educate themselves and stakeholders on best practices assessed by certification agencies rather than to foster the acquisition of climate change related certification by stakeholders. Generally, they promoted the practices employed to obtain certification, adapting where possible. The InterAmerican Institute for Cooperation on Agriculture (IICA) for example conducted seminars to promote Climate-Smart Agriculture. The Caribbean Tourism Organisation encouraged hotels to use smart technology to decrease energy and water consumption in hotels and neighbouring 
communities. The governments and private sector regularly informed special groups such as tourism operators and farmers about what was required for certification that could help them in to save energy or improve water management and land use. Technical agencies such as the meteorological agencies used certification to ensure the accuracy of instruments; transnational companies applied the certification programs used in their head offices- such as the BPTT and Nestle- and larger regional companies used the ISO 14001 criteria for environmental management systems.

\subsubsection{Promoting participation of stakeholders in overseeing sector projects}

Eighty percent of the agencies promoted participation of stakeholders in overseeing sector projects. Of these regional agencies were in the lead followed by national and international agencies. In the interviews, government officials explained that the state engaged stakeholders largely through ad hoc public sector consultations. Most government departments did not have regular standing committee meetings where non-state stakeholders could monitor the activities unless it was required by donors and funding for the same was provided through project funds. Related government ministries were often absent from climate governance steering committees: the departments of the environment/works or infrastructure generally attended but others deemed by respondents to be important (such as finance, planning, and attorney general) were generally absent.

NGOs and government officials agreed that quality of government consultations were poor: the stakeholders had insufficient notice and were often unprepared to review and discuss the documents; eighty percent or more of the time for consultations was used to explain the project or policy with little time available for feedback from participants; there was no or little reporting on how feedback from stakeholders was used.

Thirty to fifty percent of (the larger) NGOS participated in national committees often with their own resources. The private sector was less engaged, with about ten to thirty percent involvement.

\subsubsection{Monitor sector and actors' performance}

About sixty-three percent of the agencies monitored the performance of actors in the sector. Regional agencies engaged in monitoring even when this function was not in their core mandate. Less than a third of the national agencies had monitoring as part of their mandate and about one third regularly engaged in monitoring. NGO respondents noted that monitoring was an integral part of the activity of all NGOs in the region- whether they operated at the regional or localised community. Funding and resources limited the breadth and scope of their outreach. The private sector, according to some respondents from chambers of industry and commerce, was generally less engaged in monitoring the performance of other actors in the sector unless a particular state or NGO led initiative negatively affected the financial operations of one of their members. 


\subsubsection{Self-reporting}

About eighty percent of respondents used regular self-reporting as an internal accountability mechanism. In the private sector there was little external pressure to engage in self-reporting. Most public sector officials saw reporting to their ministers and to cabinet as the main way to exercise (internal) accountability. Few departments reported monthly or regularly, and in large part those that did were driven by personal initiative of department heads rather than by prescribed mechanisms. The reports contributed in a limited way to accountability: they were often a statement of activities rather than an analysis of performance against pre-established indicators. There were usually no sanction mechanisms available to internal or external stakeholders (as would be the case if reporting was for certification purposes for example).

Perhaps for this reason, some NGO respondents argued that regional government reports and national communications (to MEAs for example) were inadequate forms of external accountability but were often "fluff", reflecting "aspirational goals" rather than the substance of what the governments did during the period under review. Some agencies attempted to report through their websites, most acknowledge that they lacked resources to keep this service regularly updated and did not see those reports as an attempt to be accountable to external stakeholders.
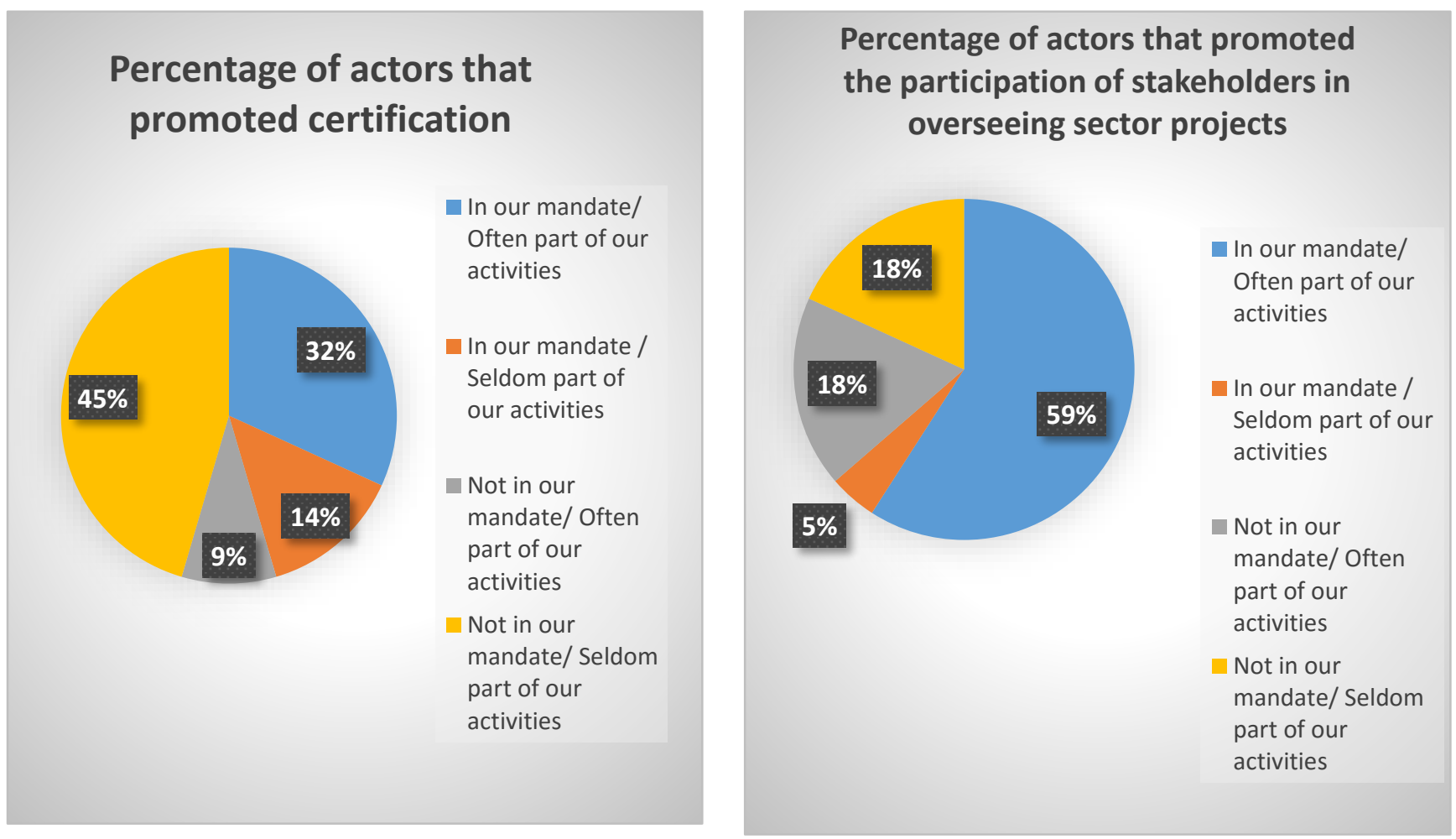


\subsubsection{Figure 13- Percentage of actors that promote certification}

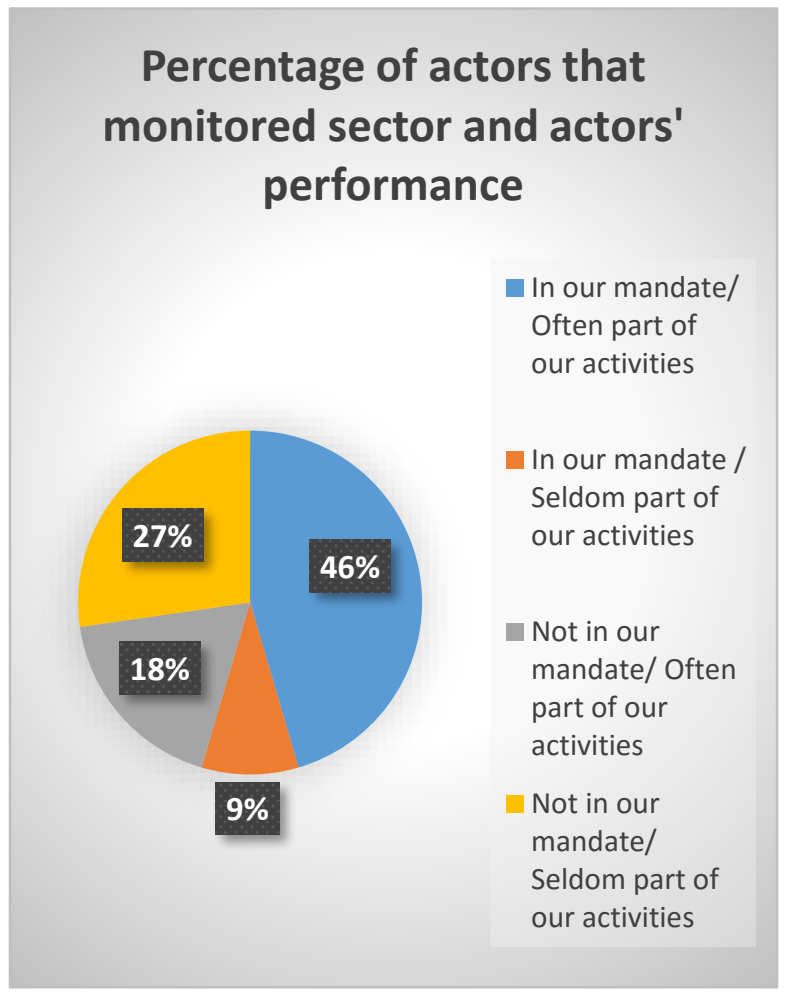

2.4.7. Figure 15- Percentage of actors that monitor sector and actors' performance
2.4.6. Figure 14- Percentage of actors that promote participation of stakeholders in overseeing sector projects

\section{Percentage of actors that regularly engaged (at least annually) in self-reporting}

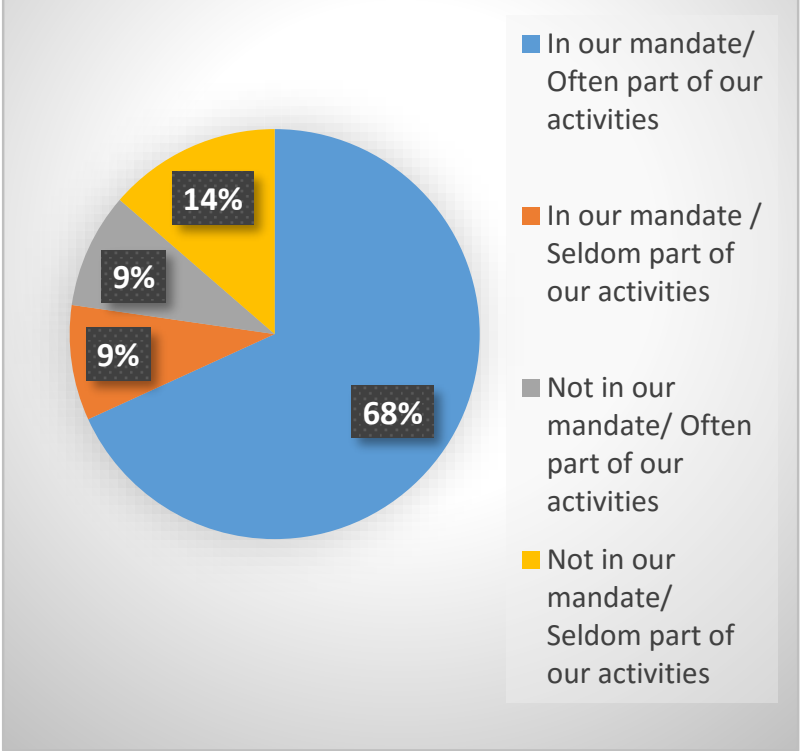

2.4.8. Figure 16- Percentage of actors that regularly engage (at least annually) in selfreporting

What accounts for the negative prognosis in the levels of accountability and the limited accountability relationships and mechanisms of accountability in climate change governance?

Imbedded in climate change governance is context. Limited resources reduce stakeholders' ability to demand accountability (Scharpf 1997). The economic context: climate actors (regional, national, private and non-state) in the region are underfunded and had to share limited climate change resources among processes that give primacy to project implementation rather than systems governance- which they saw as somewhat of a dichotomy. The need to respond with limited resources to new climate threats postponed questions of governance to cases where external funding supported that process.

All of the actors (be they regional agencies, national agencies or NGOs) agreed that the accountability deficit was due to the small size of departments the lack of trust between actors, 
the lack of readily available and updated information and analysis on actual activities of actors (especially in the public sector) and the absence of structures to promote collaboration among actors. Technocrats (often pushed by political bosses) found that they did not have the time needed for meaningful public consultation nor involvement in project design and implementation.

Most state departments related to climate governance did not have mechanisms or processes for meaningful stakeholder engagement in policy, implementation and monitoring. Missing were mechanisms to test the quality of stakeholder engagement and to mechanisms to stop or make changes to projects that failed to be accountable. No sanctions for accountability failures in project delivery were used unless they amounted to clear cases of fraudulent activity that would then involve the criminal justice system.

But there were other more situation specific causes.

Some government officials said that stakeholder consultations were politicised and were used by parliamentary oppositions to force delays in project implementation with "useless" demands for further preliminary studies or reports. Some ministers, senior officials and technocrats avoided the involvement of stakeholders external to their departments (other departments, political bosses or the public) if they foresaw competing political or technical agendas that could cause interference, objections or delay the progress of a project or implementation of a policy. Civil society was notably insufficiently mobilised and funded to monitor and demand accountability. Both NGOs and the private sector relied on the government to engage and foster accountability relationships for climate change governance. The general public were disengaged according to respondents and showed little interest in climate governance.

Yet weak systems of accountability limit climate governance effectiveness and outcomes- a factor not lost on local actors. The solution transcends climate governance and requires cultural changes in societal and governance structures towards a greater prioritisation of accountability mechanisms and relationships at both internal and external levels of agencies.

\section{CONCLUSION}

The analysis of this region supports the findings of others that agency, territoriality, architectures, and scale are key in analysing regional governance (Balsiger and VanDeveer 2012). The Caribbean context is one of economic and environmental vulnerability with governance weaknesses that are exacerbated by the more complex climate governance realities. Caribbean SIDS attempted through the CCCCC to share common regional policy and promote cooperative efforts for climate change governance. At regional and national scales accountability is higher when external funders build good governance into project deliverables.

The study revealed that climate change actors in the Caribbean are aware of the importance of accountability for climate governance. The processes to facilitate normative and relational accountability relationships were weak or missing from the formal institutional architectures of climate governance that developed since the late 1990s. Accountability mechanisms 
(certification, stakeholder participation, and performance monitoring and self-reporting) were poorly applied.

The initiatives that get most support of public and private actors tend to be those that have tangible short term benefits to the society (Underdal 2010). The study supports the findings that at lower levels of material, socio-economic, cultural and political development less focus is given to the development of governance processes (Debarbieux and Rudaz 2008).

The region's governance challenges transcend climate governance. Providing support to develop governance systems in Caribbean SIDS more generally may improve climate change governance.

At all levels, the Caribbean needs systems to foster accountability relationships- both internal and external and to develop the missing "cultures of accountability and governance". Local and suitable climate certification programs, frameworks and mechanisms for reporting and monitoring are needed that take account of: the small size and limited resources of regional, national, NGO and private sector departments; the higher levels of political involvement in decision making within government departments; the difficulties in obtaining data and keeping the general public engaged in monitoring governance processes and actors.

There are many possible solutions which may work in local contexts. They should all include accountability benchmarks and procedures for regional, government and private sector agencies; simple reporting matrices and systems to transparently provide data on climate related activities and simple systems to engage stakeholders in monitoring of climate governance processes. Some NGOs and private sector respondents noted that funding for home-grown certification programs to monitor climate governance accountability may help, since Caribbean governments are unlikely to be able to consistently lead the process.

This paper provided empirical data to contribute to the understanding of the nature of climate change governance in developing SIDS by focusing on the nature of accountability mechanisms and relationships in Caribbean SIDS. Cultures of accountability and resources for sustained participatory governance are needed as governance expands beyond the state to the networks of climate governance actors now present in the region, however small size is a permanent limitation on resources available to manage fragmented and participatory governance. The study opens the way for further research into climate change governance and accountability at local and regional scales in other developing states.

\section{Bibliography}

Adger, W. N., N. W. Arnell, and E. L. Tompkins. 2005. "Successful Adaptation to Climate Change across Scales." Global Environmental Change-Human and Policy Dimensions 15 (2): 77-86. doi:10.1016/j.gloenvcha.2004.12.005. 
Adger, W. Neil. 2006. "Vulnerability." Global Environmental Change-Human and Policy Dimensions 16 (3): 268-81. doi:10.1016/j.gloenvcha.2006.02.006.

Alleyne, Dillon, Michael Hendrickson, Willard Phillips, Kohei Yoshida, Machel Pantin, and Nyasha Skerrette. 2014. "Economic Survey of the Caribbean 2013 Improved Economic Performance with Reduced Downside Risks." LC/CAR/L.420. Studies and Perspectives. United Nations, Santiago, Chile: ECLAC Sub regional headquarters for the Caribbean. Accessed October 19. http://www.cepal.org/portofspain/noticias/documentosdetrabajo/1/52571/lcarl420.pdf.

Andonova, Liliana B., and Ronald B. Mitchell. 2010. "The Rescaling of Global Environmental Politics." Annual Review of Environment and Resources 35 (1): 255-82. doi:10.1146/annurev-environ100809-125346.

Bäckstrand, Karin. 2008. "Accountability of Networked Climate Governance: The Rise of Transnational Climate Partnerships." Global Environmental Politics 8 (3): 74-102.

Baehr, Peter R. 1975. "Small States: A Tool for Analysis." World Politics 27 (3): 456-66. doi:10.2307/2010129.

Balsiger, Jörg, and Stacy D. VanDeveer. 2012. "Navigating Regional Environmental Governance." Global Environmental Politics 12 (3): 1-17.

Barnett, Jon. 2010. "Adapting to Climate Change: Three Key Challenges for Research and Policy-an Editorial Essay." Wiley Interdisciplinary Reviews: Climate Change 1 (3): 314-17. doi:10.1002/wcc.28.

Barros, V.R., Field, C.B., D.J. Dokken, K.J. Mach, M.D. Mastrandrea, T.E. Bilir, M. Chatterjee, et al. 2014. Climate Change 2014: Impacts, Adaptation, and Vulnerability. Part B: Regional Aspects. Contribution of Working Group II to the Fifth Assessment Report of the Intergovernmental Panel on Climate Change. Cambridge, United Kingdom and New York, NY, USA: Cambridge University Press. http://www.ipcc.ch/pdf/assessment-report/ar5/wg2/WGIIAR5-FrontMatterA_FINAL.pdf.

Biermann, Frank, and Aarti Gupta. 2011. "Accountability and Legitimacy in Earth System Governance: A Research Framework." Ecological Economics 70 (11): 1856-64. doi:10.1016/j.ecolecon.2011.04.008.

Biermann, Frank, Kenneth Abbott, Steinar Andresen, Karin Bäckstrand, Steven Bernstein, Michele M Betsill, Harriet Bulkeley, et al. 2012. "Transforming Governance and Institutions for Global Sustainability: Key Insights from the Earth System Governance Project." Current Opinion in Environmental Sustainability, Open issue, 4 (1): 51-60. doi:10.1016/j.cosust.2012.01.014.

Biermann, Frank, Michele M Betsill, Susana Camargo Vieira, Joyeeta Gupta, Norichika Kanie, Louis Lebel, Diana Liverman, et al. 2010. "Navigating the Anthropocene: The Earth System Governance Project Strategy Paper." Current Opinion in Environmental Sustainability 2 (3): 202-8. doi:10.1016/j.cosust.2010.04.005.

Biermann, Frank, Michele M. Betsill, Joyeeta Gupta, Norichika Kanie, Louis Lebel, Diana Liverman, Heike Schroeder, Bernd Siebenhüner, and Ruben Zondervan. 2010. "Earth System Governance: A Research Framework." International Environmental Agreements: Politics, Law and Economics 10 (4): 277-98. doi:10.1007/s10784-010-9137-3. 
Biermann, Frank, Olwen Davies, and Nicolien van der Grijp. 2009. "Environmental Policy Integration and the Architecture of Global Environmental Governance." International Environmental Agreements: Politics, Law and Economics 9 (4): 351-69. doi:10.1007/s10784-009-9111-0.

Biermann, Frank, Philipp Pattberg, Harro van Asselt, and Fariborz Zelli. 2009. "The Fragmentation of Global Governance Architectures: A Framework for Analysis." Global Environmental Politics 9 (4): 14-40.

Briguglio, Lino, Gordon Cordina, Constance Vigilance, and Stephanie Vella,. 2010. Profiling Vulnerability and Resilience: A Manual for Small States. Commonwealth Secretariat.

Brown, Jaclyn N., Alex Sen Gupta, Josephine R. Brown, Les C. Muir, James S. Risbey, Penny Whetton, Xuebin Zhang, Alexandre Ganachaud, Brad Murphy, and Susan E. Wijffels. 2013. "Implications of CMIP3 Model Biases and Uncertainties for Climate Projections in the Western Tropical Pacific." Climatic Change 119 (1): 147-61. doi:10.1007/s10584-012-0603-5.

Browning, Christopher S. 2006. "Small, Smart and Salient? Rethinking Identity in the Small States Literature." Cambridge Review of International Affairs 19 (4): 669-84. doi:10.1080/09557570601003536.

Bugler, Will, and Benoît Rivard,. 2012. "Direct Access to the Adaptation Fund: Lessons from Accrediting NIEs in Jamaica and Senegal." September 2012. Inside Stories On Climate Compatible Development. London, UK: Climate and Development Knowledge Network. http://cdkn.org/wpcontent/uploads/2012/09/NIE_Jamaica-Senegal_InsideStory_final_WEB.pdf.

CARICOM. 2014. "Strategic Plan for the Caribbean Community 2015 - 2019 : Repositioning Caricom." Turkeyen, Guyana: CARICOM Secretariat. http://caricom.org/jsp/secretariat/EXECUTIVE\%2OPLAN\%20VOL\%201\%20-\%20FINAL.pdf.

Cash, David W, and Susanne C Moser. 2000. "Linking Global and Local Scales: Designing Dynamic Assessment and Management Processes." Global Environmental Change 10 (2): 109-20. doi:10.1016/S0959-3780(00)00017-0.

CCCCC, Caribbean Community Climate Change Centre. 2011. "Delivering Transformational Change 2011 - 21 Implementing the CARICOM 'Regional Framework for Achieving Development Resilient to Climate Change."' June. http://www10.iadb.org/intal/intalcdi/PE/2011/10128.pdf.

Cooper, Andrew F., and Timothy M. Shaw. 2012. "The Diplomacies of Small States at the Start of the Twenty-First Century: How Vulnerable? How Resilient." In The Diplomacies of Small States: Between Vulnerability and Resilience, Reprint edition, 1-18. Palgrave Macmillan.

Darylmple, Sarah Prescod, and Sarah Mason-Case. 2012. "INSIDE STORY: Strengthening Climate Resilience - the Case of Grenada." Caribbean Policy Development Centre, International Development Law Organization. http://cdkn.org/resource/inside-story-strengthening-climateresilience-the-case-of-grenada/.

Debarbieux, Bernard, and Gilles Rudaz. 2008. "Linking Mountain Identities throughout the World: The Experience of Swiss Communities." Cultural Geographies 15 (4): 497-517. doi:10.1177/1474474008094619. 
Debarbieux, Bernard, Joerg Balsiger, Dusan Djordjevic, Simon Gaberell, and Gilles Rudaz. 2015. "Scientific Collectives in Region-Building Processes (Reprinted from Environmental Science and Policy, Vol 42, Pg 149-159, 2014)." Environmental Science \& Policy 49 (May): 21-31. doi:10.1016/j.envsci.2015.02.007.

Dellas, Eleni. 2011. "CSD Water Partnerships: Privatization, Participation and Legitimacy." Ecological Economics 70 (11): 1916-23. doi:10.1016/j.ecolecon.2011.04.007.

Dingwerth, Klaus. 2008. "Private Transnational Governance and the Developing World: A Comparative Perspective." International Studies Quarterly 52 (3): 607-34. doi:10.1111/j.14682478.2008.00517.x.

Donat Castelló, Lucas, Diana Gil-González, Carlos Alvarez-Dardet Diaz, and Ildefonso HernándezAguado. 2010. "The Environmental Millennium Development Goal: Progress and Barriers to Its Achievement." Environmental Science \& Policy 13 (2): 154-63. doi:10.1016/j.envsci.2009.12.001.

Dovers, Stephen R., and Adnan A. Hezri. 2010. "Institutions and Policy Processes: The Means to the Ends of Adaptation." Wiley Interdisciplinary Reviews: Climate Change 1 (2): 212-31. doi:10.1002/wcc.29.

Dryzek, John S., and Hayley Stevenson. 2011. "Global Democracy and Earth System Governance." Ecological Economics, Special Section - Earth System Governance: Accountability and Legitimacy, 70 (11): 1865-74. doi:10.1016/j.ecolecon.2011.01.021.

Eakin, Hallie, and Maria Carmen Lemos. 2006. "Adaptation and the State: Latin America and the Challenge of Capacity-Building under Globalization." Global Environmental Change 16 (1): 7-18. doi:10.1016/j.gloenvcha.2005.10.004.

Girvan, N., and R. Bernal. 1982. "The Imf and the Foreclosure of Development Options - the Case of Jamaica." Monthly Review-an Independent Socialist Magazine 33 (9): 34-48.

Grant, Ruth W., and Robert O. Keohane. 2005. "Accountability and Abuses of Power in World Politics." American Political Science Review null (01): 29-43. doi:10.1017.S0003055405051476.

Keohane, Robert O. 1969. "Lilliputians' Dilemmas: Small States in Internatinal Politics." International Organization 23 (02): 291-310. doi:10.1017/S002081830003160X.

Keohane, Robert O., and David G. Victor. 2011. "The Regime Complex for Climate Change." Perspectives on Politics 9 (1): 7-23. doi:10.1017/S1537592710004068.

Keohane, Robert Owen, and Joseph S. Nye. 2000. "Introduction." In Governance in a Globalizing World, edited by Joseph S. Nye and John D. Donahue, 1-44. Brookings Institution Press.

Keohane, Robert Owen. 2003. "Global Governance and Democratic Accountability." In Taming Globalization: Frontiers of Governance, edited by David Held and Mathias Koenig-Archibugi, 1 edition, 130-59. Cambridge, UK : Malden, MA: Polity.

Klinke, Andreas. 2012. "Democratizing Regional Environmental Governance: Public Deliberation and Participation in Transboundary Ecoregions." Global Environmental Politics 12 (3): 79 - +.

Lahsen, Myanna, Roberto Sanchez-Rodriguez, Patricia Romero Lankao, Pauline Dube, Rik Leemans, Owen Gaffney, Monirul Mirza, Patricia Pinho, Balgis Osman-Elasha, and Mark Stafford Smith. 
2010. "Impacts, Adaptation and Vulnerability to Global Environmental Change: Challenges and Pathways for an Action-Oriented Research Agenda for Middle-Income and Low-Income Countries." Current Opinion in Environmental Sustainability 2 (5-6): 364-74. doi:10.1016/j.cosust.2010.10.009.

Lankao, Patricia Romero. 2007. “How Do Local Governments in Mexico City Manage Global Warming?" Local Environment 12 (5): 519-35. doi:10.1080/13549830701656887.

Lemos, Maria Carmen, and Arun Agrawal. 2006. "Environmental Governance." Annual Review of Environment and Resources 31 (1): 297-325. doi:10.1146/annurev.energy.31.042605.135621.

March, James G., and Johan P. Olsen. 1989. Rediscovering Institutions: The Organizational Basis of Politics. Free Press.

McMichael, A. J., C. D. Butler, and Carl Folke. 2003. "New Visions for Addressing Sustainability." Science 302 (5652): 1919-20. doi:10.1126/science.1090001.

Mitchell, Ronald B. 2011. "Transparency for Governance: The Mechanisms and Effectiveness of Disclosure-Based and Education-Based Transparency Policies." Ecological Economics, Special Section - Earth System Governance: Accountability and Legitimacy, 70 (11): 1882-90. doi:10.1016/j.ecolecon.2011.03.006.

Moore, Winston Ricardo. 2010. "The Impact of Climate Change on Caribbean Tourism Demand." Current Issues in Tourism 13 (5): 495-505. doi:10.1080/13683500903576045.

Murdiyarso, Daniel. 2010. "Climate and Development - the Challenges in Delivering the Promises: An Editorial Essay." Wiley Interdisciplinary Reviews: Climate Change 1 (6): 765-69. doi:10.1002/wcc.19.

Nilsson, Mans, and Asa Persson. 2012. “Can Earth System Interactions Be Governed? Governance Functions for Linking Climate Change Mitigation with Land Use, Freshwater and Biodiversity Protection." Ecological Economics 75 (March): 61-71. doi:10.1016/j.ecolecon.2011.12.015.

Nuenninghoff, Sybille, Michele H. Lemay, Cassandra Rogers, and Dougal Martin. 2014. "Sustainable Tourism in Belize." Inter-American Development Bank. http://publications.iadb.org/handle/11319/6795.

Nurse, L.A., R.F. McLean, J. Agard, L.P. Briguglio, V. Duvat-Magnan, N. Pelesikoti, E. Tompkins, and A. Webb,. 2014. "Small Islands." In Climate Change 2014: Impacts, Adaptation, and Vulnerability. Part B: Regional Aspects. Contribution of Working Group II to the Fifth Assessment Report of the Intergovernmental Panel on Climate Change, 29:1613-54. Cambridge, United Kingdom and New York, NY, USA: Cambridge University Press. http://www.ipcc.ch/pdf/assessmentreport/ar5/wg2/WGIIAR5-FrontMatterA_FINAL.pdf.

Okereke, Chukwumerije. 2010. "Climate Justice and the International Regime." Wiley Interdisciplinary Reviews: Climate Change 1 (3): 462-74. doi:10.1002/wcc.52.

Pittman, Jeremy, Derek Armitage, Steven Alexander, Donovan Campbell, and Marium Alleyne. 2015. "Governance Fit for Climate Change in a Caribbean Coastal-Marine Context." Marine Policy 51 (January): 486-98. doi:10.1016/j.marpol.2014.08.009. 
Samaniego, Joseluis, Luis Miguel Galindo, José Eduardo Alatorre, Jimy Ferrer, José Javier Gómez, Julie Lennox, Orlando Reyes, and Luis Sánchez. 2014. "The Economics of Climate Change in Latin America and the Caribbean Paradoxes and Challenges Overview for 2014." LC/L.3895.

Sanders, Ronald M. 1997. "The Growing Vulnerability of Small States." The Round Table 86 (343): 36174. doi:10.1080/00358539708454372.

Scharpf, Fritz W. 1997. "Economic Integration, Democracy and the Welfare State." Journal of European Public Policy 4 (1): 18-36. doi:10.1080/135017697344217.

Schouten, Greetje, and Pieter Glasbergen. 2011. "Creating Legitimacy in Global Private Governance: The Case of the Roundtable on Sustainable Palm Oil." Ecological Economics, Special Section Earth System Governance: Accountability and Legitimacy, 70 (11): 1891-99. doi:10.1016/j.ecolecon.2011.03.012.

Scott, Daniel, Murray Charles Simpson, and Ryan Sim. 2012. "The Vulnerability of Caribbean Coastal Tourism to Scenarios of Climate Change Related Sea Level Rise." Journal of Sustainable Tourism 20 (6): 883-98. doi:10.1080/09669582.2012.699063.

Selin, Henrik. 2012. "Global Environmental Governance and Regional Centers." Global Environmental Politics 12 (3): 18-37.

Simpson, Archie W. 2006. "Small States in World Politics." Cambridge Review of International Affairs 19 (4): 649-649. doi:10.1080/09557570601003379.

Smit, Barry, and Johanna Wandel. 2006. "Adaptation, Adaptive Capacity and Vulnerability." Global Environmental Change, Resilience, Vulnerability, and Adaptation: A Cross-Cutting Theme of the International Human Dimensions Programme on Global Environmental ChangeResilience, Vulnerability, and Adaptation: A Cross-Cutting Theme of the International Human Dimensions Programme on Global Environmental Change, $16 \quad$ (3): 282-92. doi:10.1016/j.gloenvcha.2006.03.008.

Underdal, Arild. 2010. "Complexity and Challenges of Long-Term Environmental Governance." Global Environmental Change 20 (3): 386-93. doi:10.1016/j.gloenvcha.2010.02.005.

Vergara, Walter, Ana R. Rios, Galindo Paliza, Luis Miguel, Pablo Gutman, Paul Isbell, Paul H. Suding, Joseluis Samaniego, and Rajendra Pachauri. 2013. The Climate and Development Challenge for Latin America and the Caribbean: Options for Climate-Resilient, Low-Carbon Development. InterAmerican Development Bank. http://publications.iadb.org/handle/11319/456.

Victor, David G. 1998. The Implementation and Effectiveness of International Environmental Commitments: Theory and Practice. MIT Press.

Voccia, Alexander. 2012. “Climate Change: What Future for Small, Vulnerable States?" International Journal of Sustainable Development \& World Ecology 19 (2): 101-15. doi:10.1080/13504509.2011.634032.

Walker, Brian, Scott Barrett, Stephen Polasky, Victor Galaz, Carl Folke, Gustav Engström, Frank Ackerman, et al. 2009. "Looming Global-Scale Failures and Missing Institutions." Science 325 (5946): 1345-46. doi:10.1126/science.1175325. 